\title{
TOURMALINITE VEINS AND BRECCIAS FROM THE SYMVOLON-KAVALA PLUTON, NORTHERN GREECE: PETROGENETIC PRELIMINARY RESULTS
}

\author{
Xydous S., Magganas A., Pomonis P. and Kokkinakis A. \\ National and Kapodistrian University of Athens, Department of Geology and GeoEnvironment, \\ Department of Mineralogy and Petrology, 15784, Athens, Greece, stxydous@geol.uoa.gr, \\ amagganas@geol.uoa.gr,ppomonis@geol.uoa.gr
}

\begin{abstract}
A previously undescribed tourmalinite rock consisting of tourmaline-rich veins and breccias occurs within the Lower Miocene Symvolon-Kavala granodiorite pluton, which intrudes the Lower Tectonic Unit of the Rhodope Metamorphic Province. Tourmaline, usually with crypto- to micro-crystalline grain size, is abundant within the matrix of breccias, also forming along with quartz and host rock clasts massive veins and injections in the fractures of the pluton. Field relations indicate that the tourmaline veins and breccias most likely formed in a brittle deformation regime, overprinting the previously developed foliation of the pluton. In addition, mineralogical and textural observations indicate that the precipitation of tourmaline was a result of cooling of B-rich hydrothermal fluids, implying for a possible magmatic-hydrothermal origin for the studied tourmalinite.

Keywords: Tourmaline, hydrothermal, fluid, metasomatism, cataclasite.

\section{Пєрí $\eta \psi \eta$}

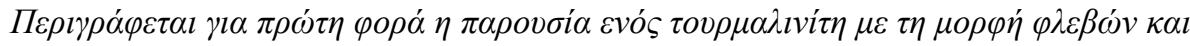

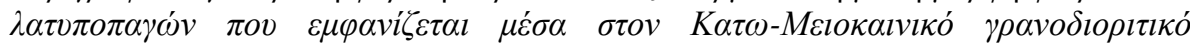

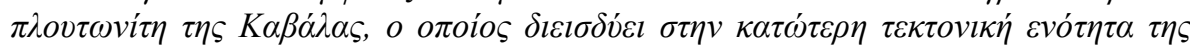

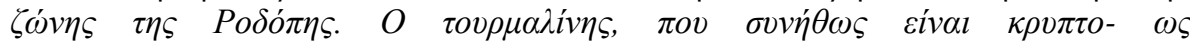
$\mu \imath \kappa \rho о \kappa \rho v \sigma \tau \alpha \lambda \lambda l \kappa o ́ \varsigma, ~ \varepsilon i ́ v \alpha l ~ \alpha ́ \varphi \theta o v o \varsigma ~ \sigma \tau \eta v ~ \kappa v ́ \rho l \alpha ~ \mu \alpha ́ \zeta \alpha ~ \tau \omega v ~ \lambda \alpha \tau v \pi o \pi \alpha \gamma \omega ́ v, ~ \varepsilon v \omega ́ ~ \alpha \pi \alpha v \tau \alpha ́$

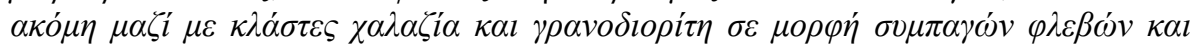

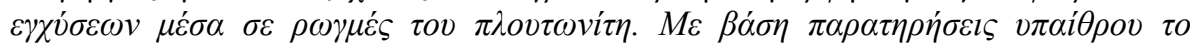

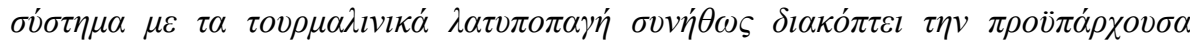

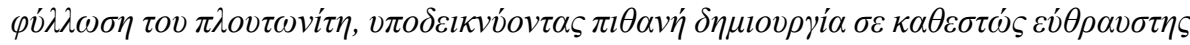

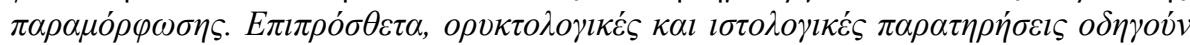

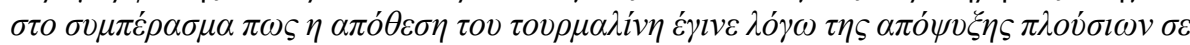

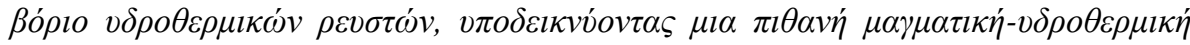

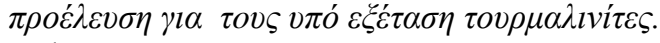

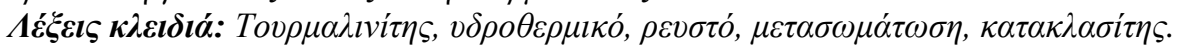

\section{Introduction}

Although tourmaline is a common accessory phase in igneous, metamorphic and sedimentary rocks, it can locally become the main constituent of particular rock-types, such as tourmalinite (e.g., Slack et al., 1984), tourmaline-bearing granite, pegmatite, greisen (e.g., Trumbull and Chaussidon, 1999), 
tourmaline-quartz breccias and breccia pipes within granites (e.g., London and Manning, 1995, Williamson et al., 2000) and metasomatic blackwalls around eclogite knockers within serpentinite mélanges (e.g., Altherr et al., 2004; Marschall et al., 2006). Tourmaline can be formed as a magmatic mineral, as a subsolidus phase and as a late hydrothermal mineral, especially at the exocontacts of granitoid plutons. The presence of tourmalines is a marker of high B activity and their chemical composition reflects the character of source rocks and might help to define the origin of the boron (Henry and Guidotti 1985; van Hinsberg et al., 2011a, b).

Tourmalinite, commonly consisting of tourmaline-quartz assemblages, usually forms cross-cutting veins and veinlets as well as pervasive replacements on a very fine scale, so that the smallest features and textures are perfectly preserved. Tourmalinization, is a special kind of alteration, characteristic of W-Sn deposits, which is commonly related to the emplacement and crystallization of peraluminus granitic magmas, with the possibility that the B-enrichment can be derived from a source containing evaporites or tourmaline-rich protolith (Harlov and Austrheim, 2013). Boron in granitic magma, particularly in combination with $\mathrm{P}$ and $\mathrm{F}$, increases intensely the solubility of $\mathrm{H}_{2} \mathrm{O}$, and reduces the viscosity of melt. This effects in enhanced partitioning of $\mathrm{B}$ into the fluid phase, the incremental solubility of silica in the fluid phase and high hydrostatic pressure during final crystallization (Pollard et al., 1987; London, 2009). The circulation of the released B-rich fluids from the crystallizing granitoid magma, in the contact aureoles causes metasomatic reactions (tourmalinization and silicification) and/or hydrofracturing in both the granite and the host rocks (Müller and Halls, 2005; Dini et al., 2008; Slack and Trumbull, 2011). When the internal pressure of the fluids exceeds the lithostatic load, the hydrofracturing triggers a breccia pipe and stockwork formation, usually associated with $\mathrm{Cu}, \mathrm{Au}, \mathrm{Mo}, \mathrm{Zn}$ and $\mathrm{Sn}$ ores and barren types, at the apices of granitic bodies (Derham and Feely, 1988; Williamson et al., 2000; Skewes et al., 2003; Dini et al., 2008; Feely et al., 2010). In the hydrofractured zones the solid rocks are fragmented and cemented by minerals crystallizing from the exsolved fluid, forming tourmaline-bearing breccias (Skewes et al., 2003; Müller and Halls, 2005; Dini et al., 2008).

In this study we present juvenile mineralogical and textural data of a previously undescribed system of tourmalinite veins and tourmaline-rich breccias from selected outcrops inside the SymvolonKavala granodiorite pluton, Northern Greece. Some preliminary implications for the petrogenesis of these peculiar and rarely found tourmaline-rich rocks are herein also reported.

\section{Regional Geology}

The Rhodope Metamorphic Province (RMP) is a polymetamorphic geological complex located in northeast Greece to southwest Bulgaria, in the hinterland of the Hellenic Subduction System (Burg et al., 1990; Bonev et al., 2006; Krenn et al., 2010; Jahn-Awe et al., 2010; Nagel et al., 2011). RMP consists of three allochthon tectonic units (Lower, Middle and Upper) and is bordered by Servomacedonian Massif in the west and Circum-Rhodope Belt in the east (e.g. Krohe and Mposkos, 2002; Bonev et al., 2006; Froitzhaim et al., 2014). Several metamorphic core complexes have been recognized in these units. The studied tourmaline-rich rocks of the Symvolon-Kavala pluton are located within the Southern Rhodope Core Complex (SRCC) representing the Lower Tectonic Unit (LTU), which is also named as Pangaeon Unit. The LTU, which comprises massive marbles, micaceous gneisses, mica schists, calc-silicate schists and amphibolites, was metamorphosed up to the upper greenschist / lower amphibolite facies. The Middle and Upper tectonic units have been metamorphosed up to ultra high pressure conditions, while during retrogration migmatization, as well as granulite to amphibolite and greenschist facies assemblanges formed.

Cenozoic igneous activity in the Rhodope is represented by Oligocene to Miocene volcanic rocks and Upper Eocene to Middle Miocene plutonic rocks. Plutonic rocks, mainly monzonite and granodiorite with lesser amounts of gabbro, are widespread in the Rhodope, although they dominate in the eastern and central parts (e.g., Christofides, 1995; Dinter et al., 1995; Eleftheriadis and Koroneos, 2003). In Kavala area the metamorphic rocks of the LTU of RMP were concordantly to 
discordantly intruded by the Kavala-Symvolon pluton along the SW-NE trend of the KavalaKomotini fault zone (Dimadis and Zachos, 1989). Kokkinakis (1977) suggests that the pluton is mainly consisting of hornblende-biotite granitic and granodioritic blastomylonites, occupying respectively the northern and the southern part of the pluton (Fig. 1). Other subordinate lithologies of the pluton include tonalitic, quartz monzonitic and quartz monzodioritic compositions. Both the pluton and the country rock are penetrated by aplitic, pegmatitic and more basic usually porphyritic dikes, the latter having an average modal composition of biotite-hornblende quartz monzodiorite. According to Christofides (1995) and Neiva et al., (1996) the pluton is a metaluminous, alpine Itype granodiorite intrusion, with lensoidal enclaves of metaluminous tonalite and diorite particularly towards its margins. Geochronological data based on U-Pb dating of titanite and ${ }^{40} \mathrm{Ar} /{ }^{39} \mathrm{Ar}$ dating of hornblende yielded an about $21 \mathrm{Ma}$, emplacement age for Kavala pluton (Dinter et al., 1995). The K-Ar biotite ages of $15.5 \pm 0.5 \mathrm{Ma}$ (Dinter and Royden, 1993) and 17.8 $\pm 0.8 \mathrm{Ma}$ (Kokkinakis, 1980) along with the 14-16 Ma Rb-Sr biotite age (Kyriakopoulos et al., 1989) originally suggested as reset metamorphic ages, are in fact the cooling ages related to the emergence of the SRCC in the footwall of the Strymon valley detachment system.

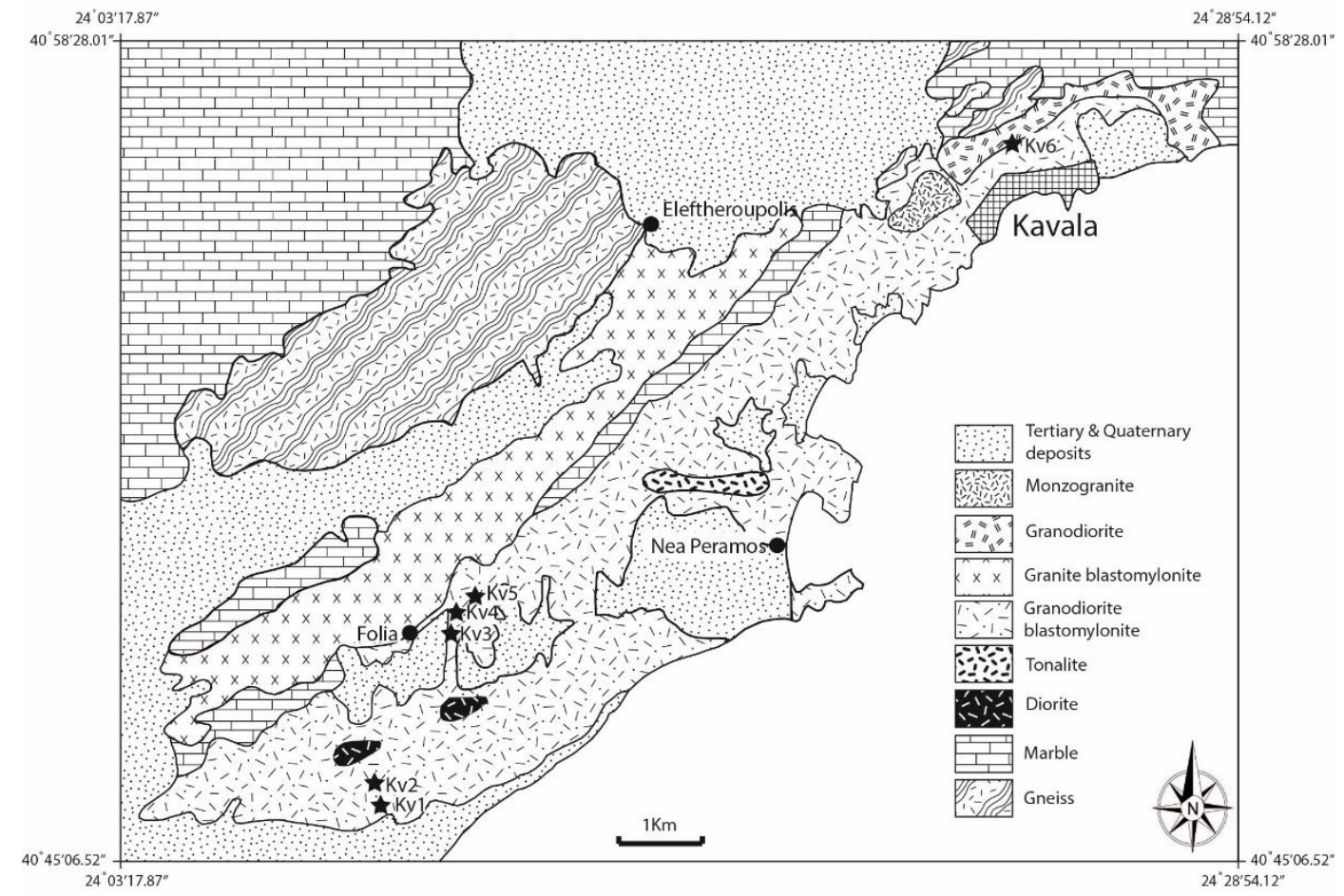

Figure 1 - Simplified geological map of the Symvolon-Kavala pluton (modified after Kokkinakis (1977) and Neiva et al. (1996). Sample locations are shown with the filled star symbol.

\subsection{Tourmaline-rich rocks}

The studied tourmaline-rich rocks occur with different frequency in the plutonic and metamorphic rocks occurring nearby Kavala city and the Symvolon Mt (Fig. 1). They are mainly found in three different forms: a) massive veins, b) cataclasites/breccias and c) injection veins (Fig. 2). The massive tourmaline veins have a blue-black colour and are completely aphanitic with a glassy fabric (Fig. 2a), which makes the discrimination from pseudotachylites extremely difficult without laboratory $\mathrm{X}$-ray diffraction methods. In cataclasites/breccias the angular clasts have a granitic or pure quartz composition, while tourmaline constitutes their matrix. This second rock type also shows a vein or 
layered structure with thickness that varies from few $\mathrm{mm}$ to about one meter. Their tourmaline matrix, which also shows a dark blue to black colour, is locally disrupted by the grey to white clasts occurring with greater abundance in breccias thicker than $1 \mathrm{~cm}$ (Fig. 2b, c). Tourmaline injection veins (Fig. 2d) are commonly developed into a complicated network, which finally seems to feed/infiltrates the breccias. Another type of tourmaline-rich rock maybe represented by fracture filling tourmaline-rich material spatially associated with microfault and joint systems. It frequently has a thickness not exceeding few $\mathrm{cm}$ and a mirror like polished surface with slickensides indicating a movement which is postdating the tourmaline precipitation.

The most important occurrence of the tourmaline-rich rocks is in the area of Mavri Petra in the Symvolon Mt (sample locations Kv1-Kv5, in Fig. 1). In this area the massive veins and breccias are abundant and are found within the granodioritic blastomylonite, and in close spatial association with aplitic dikes. The tourmaline-rich vein system is mostly developed along a NW-SE to NNW-SSE trend with moderate to steep dip angles (Fig.2a), under a brittle deformation regime. Field relations show that the tourmaline bearing cataclastic system seems to be overprinting the previous mylonitic foliation of the pluton.
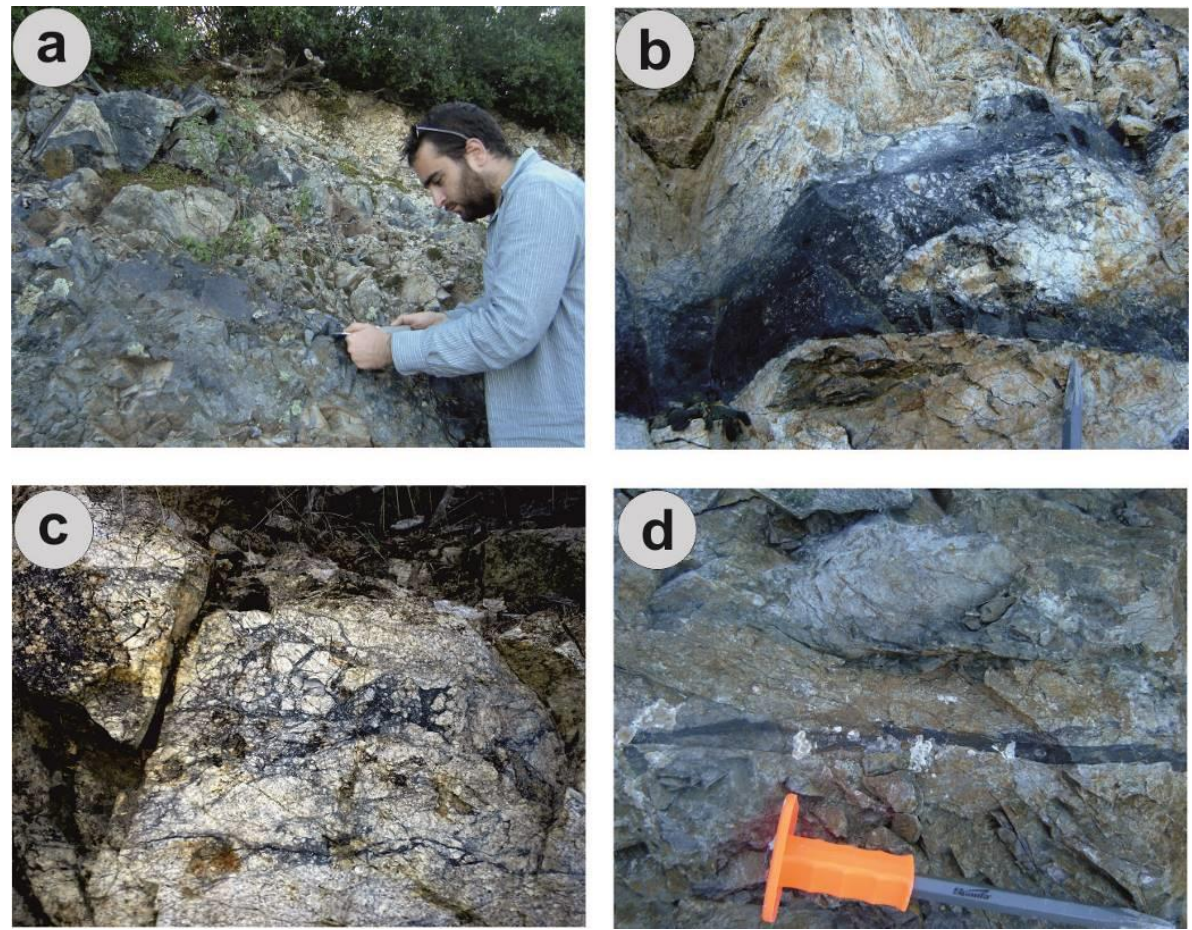

Figure 2 - Outcrop photographs of the tourmaline-rich rocks in the field. Fine-grained tourmaline is found in the forms of: a) massive veins, b, c) matrix within granitic cataclasites/breccias and d) injection veins. Field of view for picture (c) is about $1 \mathrm{~m}$.

\section{Materials and Methods}

Fifteen samples of tourmaline-rich rocks (both veins and breccias) and host granodiorite were pulverized for X-Ray Diffraction analysis, obtained using a SIEMENS D-5005 type diffractometer with $\mathrm{Cu}$ tube, in order to verify the presence of tourmaline. The mineralogical phases were determined with the software DIFRAC PLUS 2004, EVA ver. 10 at the laboratories of the NKUA, Faculty of Geology and Geo-Environment. Except the evaluation of the bulk mineralogy on the $\mathrm{XRD}$, more than twenty-five thin sections of the most representative tourmaline bearing rocks were 
constructed in order to investigate the textural relationships of the studied material mostly under a ZEISS AXIOSKOP 40 polarizing microscope.

\section{Results}

\subsection{X-Ray Diffraction analysis}

X-Ray Diffraction patterns of orientated powder mounts revealed the bulk mineralogy of the massive tourmaline veins and tourmaline breccias. Tourmaline and quartz are essentially present in all the studied samples. Other components are orthoclase, plagioclase and white mica, which represent alongside quartz the granodioritic clasts inside the breccias. Based on XRD patterns morphology and recognized mineral phases we can divide the studied samples in two groups: Group 1 (Fig. 3a), represented by samples composed only of tourmaline and quartz and Group 2 (Fig. 3b) where tourmaline coexists with quartz, orthoclase, albite and white mica. In combination with hand specimen and thin section petrography Group 1 samples are interpreted as massive tourmalinequartz veins and Group 2 as tourmaline-cemented granodioritic breccias. However, as semiquantitative analysis reveals the tourmaline amount in both groups exceeds $15 \%$, moreover being higher than $50 \%$ in massive veins, most of the studied rocks can be characterized as tourmalinites (cf. Harlov and Austrheim, 2013).
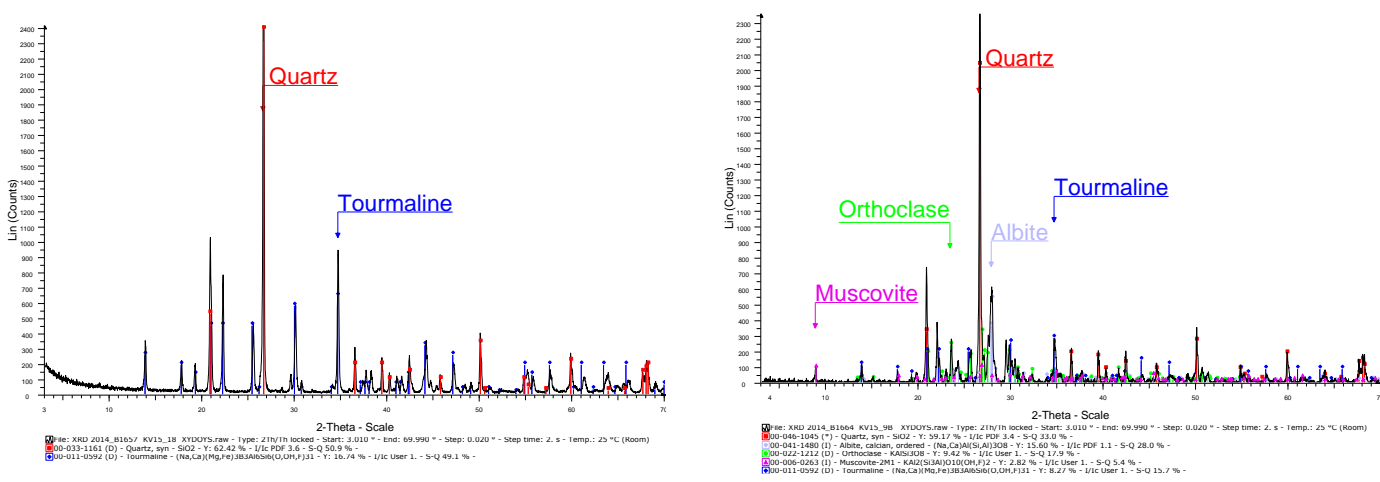

Figure 3 - XRD patterns of two selected tourmalinite samples (Kv15-9B, Kv15-18).

\subsubsection{Petrography}

All the studied samples are mainly composed of angular granodioritic rock fragments, mineral clasts and a fine-grained to aphanitic matrix. Even the massive tourmaline veins reveal under the microscope a cataclastic texture, in a similar manner as the tourmaline breccias. Microscopic textures are quite similar to macroscopic-scale textures, and effects of brittle deformation and cataclasis are very clear in most of the samples. Clear evidence of ductile deformation seems to be absent from the studied samples, in contrast to the host granodiorite, which presents a well-defined gneissic texture. However, in places tourmaline crystals and quartz fragments present orientation of their elongated c-axes.

The clastic material inside the breccias is mainly composed of angular to subrounded granodioritic fragments and monomineralic clasts, mainly quartz and K-feldspar, derived from the host rocks, giving the rock a poorly sorted appearance (Fig.4a). The fragments are characterized by ribbon quartz textures, K-feldspars with deformation twins and domino fragmented porphyroclasts of Kfeldspars and plagioclase (Fig.4b). It should be noticed that plagioclase occurs mainly inside the rock clasts, and it is nearly absent in the form of isolated grains inside the matrix. Quartz generally has angular outlines with numerous internal fractures; recrystallization and subgrain formations are visible and undulose extinction is widespread. 
Between the rock and mineral fragments, a fine-grained to aphanitic tourmaline-rich matrix is present covering at least $15 \%$ of the surface in the studied thin sections (see Fig.4a).
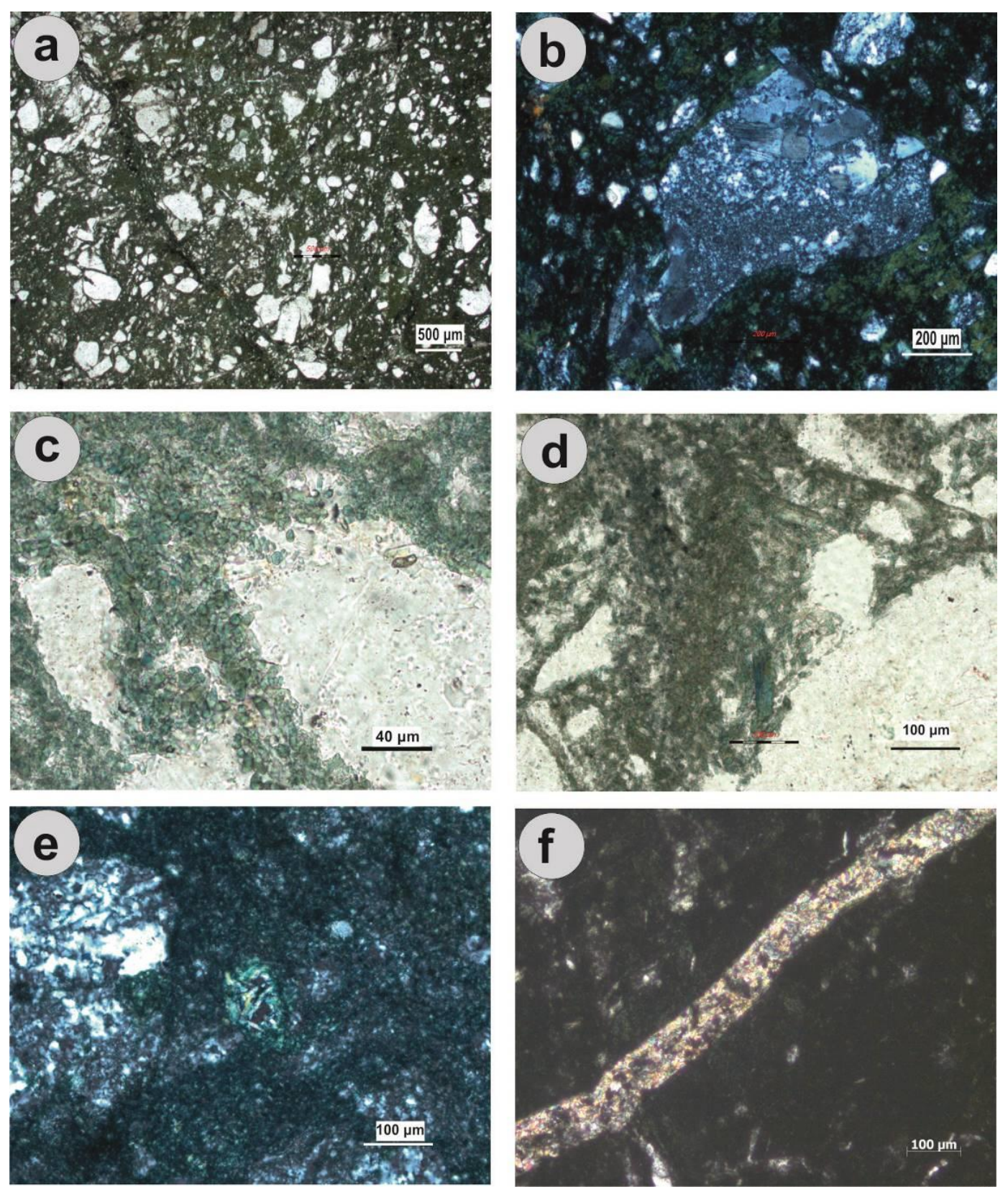

Figure 4 - Photomicrographs of the studied samples under the polarizing microscope: a)Typical view of the tourmaline-breccias showing abundant rock and mineral fragments embedded in a aphanitic tourmaline matrix (KV15/9, PPL), b) Angular fragment of the host granodiorite (KV15/9, XPL), c) Euhedral tourmaline microcrystals of the matrix surrounding subrounded quartz clasts (KV15/9, PPL), d) Tabular, subhedral tourmaline crystal with distinct zoning surrounded by the matrix (KV15/9, PPL), e) Orbicular intergrowth of tourmaline and quartz crystals (KV15/9, XPL), f) White mica + K-feldspar + quartz veinlet crosscutting the matrix of the tourmaline breccias (KV15/18, XPL). 
The tourmaline-rich matrix appears with a light- to dark green color under plane polarized light and with a blue-green color in crossed polars, presenting subsequently a weak to moderate green pleochroism. In some cases, the aphanitic matrix appears nearly isotropic. Under high magnifications (500x), tiny (up to $30 \mu \mathrm{m}$ long and 5-10 $\mu \mathrm{m}$ wide) euhedral to subherdral tiny tourmaline crystals are present, forming a nearly equigranular crypto- to microcrystalline matrix (Fig.4c). Besides the aphanitic matrix, tourmaline is present in two other distinct but rarely occurring forms in the studied thin sections, namely zoned and orbicular tourmalines. Zoned tourmalines are subhedral to anhedral, elongated (up to $120 \mu \mathrm{m}$ long), corroded tourmaline crystals with distinct zonation. They are present within the aphanitic matrix (Fig.4d) forming a microporphyric texture, resembling clasts in a similar manner with the host rock fragments. The orbicular tourmalines consist of light green euhedral tourmaline microcrystals surrounding a core of undeformed quartz grains (Fig.4e).

Another noteworthy petrographic feature is the presence of secondary quartz, K-feldspar and white mica in fractures and veinlets with crosscutting relation to the tourmaline matrix (Fig.4f).

\section{Discussion and Conclusions}

The tourmalinite rocks of the Symvolon-Kavala pluton, can be broadly classified as magmatichydrothermal breccias, as they match distinguishing criteria such as the presence of angular to subrounded rock fragments and high temperature cementing phases (Sillitoe, 1985; Lawless et al., 1998). Lawless et al. (1990) suggested that this kind of breccias are likely formed by the release of juvenile magmatic volatiles derived from partial melting of crustal rocks.

Field relations indicate formation rather in a brittle deformation regime, postdating the mylonitization event, which is responsible for the widespread gneissic texture of the intrusion. The locally occurring oriented c-axes of tourmaline crystals and quartz can be interpreted as a result of cataclastic flow. Hydrofracturing of the granodioritic host rock and fracture propagation seems to be a result of B-rich hydrothermal solution responsible for the pervasive tourmalinization. This is commonly resulting from the formation of mineralized or barren breccias pipes and stockworks around granitic cupolas. These structures lack from the study area, probably due to focused fluid flow within shear zones parallel to the regional NW-SE trending, as suggested by Demirel et al. (2009) for a similar case within the Kerkenez monzonite-granite massif (Central Anatolian Crystalline Complex, Turkey).

Mineralogical and textural observations during this study, revealed two types of tourmaline-bearing rocks: a) tourmaline-cemented granitic breccias and b) massive tourmaline-quartz veins. Massive tourmaline-quartz veins are depleted in material derived from the host rock, probably due to high water/rock ratios. Penetrative B-rich fluid circulation triggered metasomatic reactions that resulted in the precipitation of tourmaline in the aphanitic matrix. Although replacement textures have not been observed, the absence of biotite and hornblende from the studied samples, could be attributed to the formation of idiomorphic tiny tourmaline crystals at the expense of biotite and hornblende. The decomposition of the later phases could have probably contributed to the offer of the essential $\mathrm{Fe}$ and $\mathrm{Mg}$ amounts for the tourmaline crystallization. The small size of tourmaline, combined with its great abundance, indicates precipitation from a rapidly cooling hydrothermal fluid under high nucleation and low crystal growth rates.

Corroded tourmaline porphyroclasts (up to $120 \mu \mathrm{m}$ ) within the aphanitic matrix (see Fig.4d) may represent an early boron-rich metasomatic event, as tourmaline has not been identified as an accessory phase in the magmatic rocks of the study area. In opposite, euhedral tourmaline crystals followed by crystallization of undeformed quartz grains may indicate formation within open space miarolithic microcavities under low pressure and by late stage boron-bearing fluids. In addition, the presence of white mica, K-feldspar and quartz in late veinlets crosscutting the tourmaline matrix probably suggests that the circulation of hydrothermal fluids is continued after the successive tourmalinization events. 
The preliminary results presented in this study, verify the presence of tourmaline in the studied breccias and suggest a magmatic-hydrothermal origin. Several plausible scenarios can be suggested for the source of boron, including exsolution of B-rich magmatic-hydrothermal fluids from the host granodioritic rock. Upcoming work should include detailed electron probe microscopy in order to classify the tourmaline species and make more accurate hypothesis for their formation environment. In addition, stable and radiogenic isotopic studies, which also are anticipated for the near future, can provide valuable information about the source of boron and the genetic relationship of the breccias with the host granodiorite.

\section{References}

Altherr, R., Topuz, G., Marschall, H., Zack, T. and Ludwig, T. 2004. Evolution of a tourmaline-beari ng lawsonite eclogite from Elekdag area (Central Pontides, N Turkey): evidence for infiltratio n of slab-derived B-rich fluids duringexhumation, Contrib. Mineral. Petrol., 148, 409-425.

Bonev, N., Burg, J.-P. and Ivanov, Z., 2006. Mesozoic-Tertiary structural evolution of an extension al gneiss dome-The Kesebir-Kardamos dome, eastern Rhodope (Bulgaria-Greece), Int. J. E arth Sci. (Geol Rundsch), 95(2), 318-340, doi: 10.1007/s00531-005-0025-y.

Burg, J.-P., Ivanov, Z., Ricou, L.-E., Dimov, D. and Klain, L., 1990. Implications of shear-sense criteria for the tectonics evolution of the Central Rhodope massif, southern Bulgaria, Geology, 18, 451-454, doi: 10.1130/0091-7613(1990)018.

Christofides, G., 1996. Tertiary magmatism in the Greek Rhodope Massif, northern Greece: Granitic pl utons. In: Knezevic, V. and Krstic, B., eds., Terranes of Serbia: The Formation of the Geologic F ramework of Serbia and the Adjacent Regions, University of Belgrade, Belgrade, 1, 55-160.

Christofides, G., Neiva, A., Soldatos, T. and Eleftheriadis, G., 1995. Petrology of the Kavala plutonite (Eastern Macedonia, Greece), Proc. XV Congress CBGA, Athens, Bull. Geol. Soc. Greece, Spec. Publ., 4(2), 489-494.

Demirel, S., Göncüoĝlu, C., Topuz, G. and Isik, V., 2009. Geology and chemical variations in Tourmaline from the Quartz-Tourmaline Breccias within the Kerkenez Granite-Monzonite Massif, Central Anatolian Crystalline Complex, Turkey, The Canadian Mineralogist, 47, 787-799.

Derham, J.M. and Feely, M., 1988. A K-feldspar breccia from Mo-Cu stockwork deposit in the Galway granite, west of Ireland, J. Geol. Soc., London, 145, 661-667.

Dimadis, E. and Zachos, S., 1989. Geological and tectonic structure of the metamorphic basement of the Greek Rhodope, Geologica Rhodopica, 1, 122-130.

Dini, A., Mazzarini, F., Musumeci, G. and Rocchi, S., 2008. Multiple hydrofracturing by boron-rich fluids in the Late Miocene contact aureole of eastern Elba Island (Tuscany, Italy), Terra Nova, 20, 318-326.

Dinter, D., MacFarlane, A., Hames, W., Isachsen, C., Bowring, S. and Royden, L., 1995. U-Pb and 40Ar/39Ar geochronology of the Symvolon granodiorite: implications for the thermal and structural evolution of the Rhodope metamorphic core complex, northeastern Greece, Tectonics, 14, 886-908.

Dinter, D.A. and Royden, L, 1993. Late Cenozoic extension in northeastem Greece: Strymon Valley detachment and Rhodope metamorphic core complex, Geol., 21, 45-48.

Eleftheriadis, G. and Koroneos, A., 2003. Geochemistry and petrogenesis of post-collisonal Pangeon granitoids in central Macedonia, northern Greece, Chemie der Erde, 63, 364-389.

Feely, M., Selby, D., Hunt, J. and Conliffe, J., 2010. Long-lived granite-related molybdenite mineralization at Connemara, western Irish Caledonides, Geol. Mag., 147, 886-894.

Froitzheim, N., Jahn-Awe, S., Frei, D., Wainwright, A., Maas, R., Georgiev, N., Nagel, T.J. and Pleuger, J., 2014. Age and composition of meta-ophiolite from the Rhodope Middle Allochthon (Satovcha, Bulgaria): a test for the maximum-allochthony hypothesis of the Hellenides, Tectonics, 32.

Harlov, D.E. and Austrheim, H., 2013. Metasomatism and the Chemical Transformation of Rock, Lecture Notes in Earth System Sciences, doi: 10.1007/978-3-642-28394-9_1, SpringerVerlag, Berlin, Heidelberg. 
Henry, D.J. and Guidotti, C.V., 1985. Tourmaline as a petrogenetic indicator mineral: an example from the staurolite- grade metapelites of NW Maine, American Mineralogist, 70, 1-15.

Jahn-Awe, S., Froitzheim, N., Nagel, T.J., Frei, D., Georgiev, N. and Pleuger, J., 2010. Structural and geochronological evidence for Paleogene thrusting in the western Rhodopes, SW Bulgaria: Elements for a new tectonic model of the Rhodope Metamorphic Province, Tectonics, 29.

Kokkinakis, A., 1977. Das Intrusivgebiet des Symvolon-Gebirges und yon Kavala in Ostmakedonien, Griechenland. - Diss. Univ. Miinehen. - 255 + XIII S., 208 Abb., 29 Tab., 8 Kt., 1 B1, Miinehen.

Kokkinakis, A., 1980. Altersbeziehungen zwischen Metamophosen, mechanischen Deformationen und Intrusionen am Südrand des Rhodope-Massivs (Makedonien, Griechenland) Geol, Rundschau, 69, 726-144.

Krenn, K., Bauer, C., Proyer, A., Klötzli, U. and Hoinkes, G., 2010. Tectonometamorphic evolution of the Rhodope orogen, Tectonics, 29, TC4001.

Krohe, A. and Mposkos, E., 2002. Multiple generations of extensional detachments in the Rhodope Mountains (N. Greece): evidence of episodic exhumation of high-P rocks. In: Blundell, D.J., Neubauer, G. and Von Quadt, A., eds., The Timing and Location of Major Ore Deposits in an Evolving Orogen, Geological Society of London, Special Publication 204, 151-178.

Kyriakopoulos, K., Pezzino, A. and Del Moro, A., 1989. Rb-Sr geochrological, petrological and structural study of the KavaIa plutonic complex (N. Greece), Bull. Geol. Soc. Greece, 23, 545-560.

Lawless, J.V. and White, P.J., 1990. Ore-Related Breccias: A Revised genetic classification, with particular reference to epithermal deposits, 12th New Zealand Geothermal Workshop.

Lawless, J.V., White, P.J., Bogie, I., Paterson, L.A. and Cartwright, A.J., 1998. Appendix 1: Genetic Classification of Breccias, Ore Deposits and Magmatic-Hydrothermal Processes (Workshop manual), Kingston Morrison consulting, 20 pp.

London, D., 2009. The origin of primary textures in granitic pegmatites, Canad. Mineral, 47, 697-724.

Marschall, HR, Ludwig, T, Altherr, R, Kalt, A. and Tonarini, S., 2006. Syros metasomatic tourmaline: Evidence for very high-811B fluids in subduction zones, Journal of Petrology, 47, 1915-1942.

Müller, A. and Halls, C., 2005. Rutile - the tin-tungsten host in the intrusive tourmaline breccia at Wheal Remfry, SW England. In: Jingwen, $\mathrm{M}$ and Bierlein, F.P., eds., Mineral Deposit Research, Meeting the Global Challenge, 441-444.

Nagel, T.J., Schmidt, S., Janak, M., Froitzheim, N., Jahn-Awe, S. and Georgiev, N., 2011. The exposed base of a collapsing wedge: The Nestos Shear Zone (Rhodope Metamorphic Province, Greece), Tectonics, 30, TC4009, doi: 10.1029/2010TC002815.

Neiva, A., Christofides, G., Eleftheriadis, G. and Soldatos, T., 1996. Geochemistry of granitic rocks and their minerals from the Kavala pluton, northern Greece, Chemie der Erde, 56, 117-142.

Pollard, P.J., Pichavant, M. and Charoy, B. 1987. Contrasting evolution of fluorine- and boron-rich systems, Miner Depos, 22, 315-321.

Sillitoe, R.H., 1985, Ore-related breccias in volcanoplutonic arcs, EconomicGeology, 80, 1467-1514.

Skewes, M.A., Holmgren, C. and Stern, C.R., 2003. The Donoso copper-rich, tourmaline-bearing breccia pipe in central Chile: petrologic, fluid inclusion and stable isotope evidence for an origin from magmatic fluids, Miner Depos, 38, 2-21

Slack, J.F. and Trumbull, R.B., 2011. Tourmaline as a recorder of ore-forming processes, Elements, 7, 321-326.

Trumbull, R.B. and Chaussidon, M., 1999. Chemical and boron isotopic composition of magmatic and hydrothermal tourmalines from the Sinceni granite-pegmatite system in Swaziland, Chem. Geol., 153, 125-137.

van Hinsberg, V.J., Henry, D.J. and Dutrow, B.L., 2011a. Tourmaline as a petrologic forensic mineral: A unique recorder of its geologic past, Elements, 7, 327-332.

van Hinsberg, V.J., Henry, D.J. and Marschall, H.R., 2011b. Tourmaline: An ideal indicator of its host environment, Canadian Mineralogist, 49, 1-16.

Williamson, B.J., Spratt, J., Adams, J.T., Tindle, A.G. and Stanley, C.T., 2000. Geochemical constraints from zoned hydrothermal tourmalines on fluid evolution and $\mathrm{Sn}$ mineralization: an example from fault breccias at Roche, SW England. J Petrol, 41, 1439-1453. 